\title{
Influence of School Environment on Adjustment of Form one Students To Secondary School In Uasin Gishu County, Kenya.
}

\author{
Sarah. \\ P.O. Box 8135-30100, Eldoret. Dept of Educational Psychology, University of Eldoret, Kenya
}

\begin{abstract}
Educationists need to understand what secondary school adjustment phenomenon and particularly what form one students require for adjustment and retention in school hence benefit from school during and after secondary. Student academic performance and adjustment are linked with interest in school environment particularly physical facilities. School adjustment refers to ability to adapt and successful survive in a new physical and social environment with new people, routines, rules and regulation, physical structures and curriculum. The specific objective of the study was to determine the influence of school environment on adjustment form one students to secondary school. Bronfenbrenner"s ecological theory was employed in the study which assumes that behavior is as a result of personal attributes and the environment contributions. The study employed explanatory survey research design. The target population was 207 heads of schools, 207 head s of counseling department, and 14,043 form one students in Uasin Gishu County. Stratified, purposive and simple random sampling techniques were used to select the schools, head teachers, counselors and student"s respectively. The sample size was 100 head teachers, 100 heads of counseling department and 389 form one students. Self administered sets of questionnaire and focus group discussion were used in data collection. The study used mixed method was used. For quantitative data, questionnaire data was coded and entered into the computer using SPSS. Both descriptive such as frequencies, percentages, mean and standard deviation as well as inferential statistics and more specifically Pearson correlation and regression were used. The findings were $(\mathrm{r}=0.585, \rho<0.05)$, and $(\beta=0.585, p=0.05)$ respectively. Qualitative data was analyzed based on emerging themes. The results indicate a significant influence of school environment on adjustment of form one students to secondary school. The study concluded that a conducive physical school environment enhance adjustment of form one students to secondary school.
\end{abstract}

Key words: secondary school adjustment, school physical environment, and classroom climate

\section{INTRODUCTION}

Secondary school adjustment is a broad construct which consists of many different aspects such as school satisfaction, school engagement, academic achievement, and pro-social behavior. Therefore, educationists need to be aware of what needs to be done to help their form one students adjust and benefit from school since well-adjusted students usually enjoy most of the school activities and value what they learn. They are positively involved in classroom activities and receive high grades (Kiuru, Nurmi, Aunola, Salmela - Aro, 2009). On the contrary, poor school adjustment may leads to: low academic achievement, behavioral problems, discordant educational aspirations and even school dropout (Vasalampi, Salmela-Aro, Nurmi, 2009). Consequently, school dropout poses a serious problem since early school dropout jeopardizes future career, employment opportunities and life chances for such students (Darmody, 2008; Frey, Ruchkin, Martin, \& Schwab-Stone, 2009). The hypothesis: There is no significant influence of school environment on adjustment of Form One students to secondary school guided the study. The significance of the study contribute was to filling of knowledge gap in adjustment of form one students to secondary school studies. This was because there exist very scanty literature on adjustment of form one students to secondary school, yet form one students admission to secondary school is done annually in Kenya.

\subsection{Purpose and Statement of the Study}

The aim of this study was to examine the influence of school environment on adjustment of form one students to secondary school in Uasin Gishu County. School transition from primary to secondary by extension implies academic, social and environmental change (Benner \& Graham, 2009) hence the need for adjustment to these changes. Adjustment or adaptation is important in order for students to survive and fit-in well in the new physical environment hence less worries about getting lost because of a large physical school environment (Logan \& Skamp, 2008). Positive school adjustment may lead to school retention, academic success as well as general well-being of the form one students. On the contrary, failure to adjust may lead to a decline in students" motivation, absenteeism, decline in academic achievement, drug abuse and worse, school dropout (Lerner \& Steinberg, 2009). This implies that school climate has link on social adjustment. A conducive school 
environment may lead to school retention, academic success as well as general well being of the form one students. On the contrary, a harsh school environment may lead to decline in academic achievement, drug abuse, absenteeism, and even school dropout (Lerner \& Steinberg, 2009). Research has it that school dropout is as a result of trouble or challenges of coping with a vast of things in the new physical environment (Dockett \& Perry, 2007), in secondary school. Poor school adjustment leading to school dropout poses a serious problem since early school dropout jeopardizes future career, employment opportunities and life chances for such students (Darmody, 2008; Frey et al., 2009). Increased primary to secondary school transition has been taken care off through Free Secondary Education (FSE) funding policy by the Kenyan government (Republic of Kenya, 2008) but not much has been put in place to address form one student adjustment. Further, previous Kenyan studies have only focused on factors hindering transition from primary to secondary school, relationship among school Adjustment, Gender and Academic Achievement amongst Secondary School Students and influence of parent adolescent communication on psychological adjustment of secondary school students (Dube, 2011; Winga, Agak \& Ayere, 2011; Disiye, 2012) respectively. These studies are related to this study, but they have not directly addressed the construct of adjustment of form one students to secondary school. This study, therefore, sought to establish the influence of school environment on adjustment of form one students to secondary school.

\section{LITERATURE REVIEW}

Students "e perceptions of school climate determine students" academic outcomes. According to Wang and Holcombe (2010), children"s perceptions of school climate significantly affect academic performance only through student academic engagement rather than directly. This means that improvement school climate is important in improving students" academic outcomes. Conducive school climate is important because academic scores have become the destiny charters for Kenyan students. Hence, almost every secondary school student bears the heavy baggage of the expectations of parents and teachers. The environment created in the school as accelerates or retards the development of any student she or he spend most part of their day attending school and engaging in school activities. School contributes to the total educational and socialization process directed to the development of personality of a student (Shah, 2012). School environment in this study included physical facilities set up and the learning recourses available. Logan and Skamp (2008) assert that principal concerns on the adjustment of form one students to secondary school include: difficulty in locating classroom and other structures hence getting lost and keeping up on academic performance. Other concerns include decreased opportunities for independent work, differences in the style of teaching and too little opportunity for personal study. This may lead to social and psychological unsettledness. In fact, negative consequences of failure to adjust may crop up including drugs and alcohol abuse, absenteeism and worse of them all is school dropout (Ding, 2008).

Crandell (2009) pointed out that the availability of facilities such water and toilet facilities, sports facilities, and learning materials such as textbooks in school goes a long way to motivate the adolescent students as they adjust and remain in secondary school. The motivation here involves the inner states and processes that prompt direct and sustain activity. This motivation influences the rate of student learning, the retention of information and performance, and materials that might have a disproportionate impact on girls' attendance and performance.

Both social and physical environments of the school are tremendously influential as both a context for and as direct influence on adolescent development. For Secondary students, warmth is perceived as a key feature of high-quality peer relationships and highly functional school and classroom climates. Peer interactions that is warm, create a climate of comfort and help meet students" need for relatedness (Ciani, Middleton, Summers, \& Sheldon, 2010; Martin \& Dowson, 2009). This is not surprising because adolescents spend more time in school than they spend in any place outside their homes. Because of the much amount of time adolescents spend in school, the school need to provide the context or environment within which adolescents

develop (Lerner \& Steinberg, 2009). According to Achoka, Odebero, Maiyo and Mualuko (2 007) students in Kenya ${ }^{\text {ee }}$ s secondary schools take four years to complete the course. The development can either take a positive or negative dimension depending on the perceived and real environmental provision by the school.

The school policies and practices shape adolescents" development through the experiences students have while in school. There are various levels of school organization such as classrooms, school buildings, school districts and the larger community which all interact to impact adolescent development and behaviors (Lerner \& Steinberg, 2009). Ultimately, this may imply that a conducive school environment translate to a positive perception hence school high retention and completion rates.

\section{RESEARCH MATERIALS AND METHODS}

Self administered sets of questionnaire and focus group discussion were used in data collection. The study used mixed research method hence collection of quantitative and qualitative data. The study employed 
two assets of questionnaire: a set for form one students and another one for administrators to gather quantitative. The questionnaires seemed appropriate for the study as it provided an opportunity for the researcher to carry out an inquiry on the influence of school environment on adjustment of form one students to secondary school thus making the study findings more dependable and reliable (Kothari, 2008, Cohen, Marion \& Morrison, 2005). Qualitative data was gathered using focus group interview and participant observation. Focused group interview or discussion and participant observation used in the generation of data allowed the study to bridge the gap that exist when one relies only on published accounts (Saunders, Lewis \& Thornhill , 2003). The study utilized various sampling techniques for the various target population groups as follows: schools, head teachers and heads of counseling department, and students. This study employed stratified sampling technique to sample schools which involved dividing the schools into strata or groups based on categories of schools. The first category was grouping of schools in terms of sex, which included the single sex and mixed schools. Second category was groups of schools in terms of levels: National, Extra County, County and District level of secondary schools. This categorization of secondary schools was deemed crucial because samples were to be drawn proportionately. This stratified sampling method was useful in this research because it gave a blend of randomization and categorization, thereby enabling both qualitative and quantitative method of data collection to be employed in this research. Moreover, the grouping of the population into relevant strata met that the samples were more representative as it ensured that each of the strata was represented proportionally within the sample (Saunders et al., 2003).

\subsection{Data Analysis, Presentation, and Interpretations}

The objective of this study was to determine the influence of school environment on adjustment of form one student to secondary school. The research question was: To what extent does the school environment influence adjustment of form ones to secondary school? The study sought from students the influence of school environment on adjustment of form one students to secondary school. The questionnaire (Appendix II, Part: D), students" information concerning influence school environment on adjustment had some items adapted and others developed. This data results has been presented on Table 1.1 (see Appendices Table 1.1). From the findings students agreed and to most of the items concerning school and class environment. For instance, they agreed that administrator, teachers and non teaching staff are caring, understanding and accommodative and that they were encourage us to participate in extra curricula activities ( sports, games clubs etc) with means $(4.17 ; 4.30)$ respectively. They agreed that they were not bullied by other students, classmates were supportive and teachers were approachable with means $(4.30 ; 4.11 ; 4.20)$ in that order. These could have led to positive adjustment of form one students to secondary school. However, it is important to note that form one students disagreed (2.19) that the secondary school was similar in terms of physical facilities and human populations to their former primary school. This implies that secondary school was larger than their in terms of the population of students, administrators and teachers as well as structures and facilities. Further, buildings and structures were not well labeled hence leading to students difficulty in locating buildings and structures with means (2.76).

This difficulty in locating venues or buildings may have contributed to form one students getting lost hence failure to adjust smoothly to the new school environment especially on their initial days in secondary school.

To establish the actual strength of the relationship between school environment and adjustment of form one students to secondary school, the study performed Pearson"s Product Moment correlation coefficient. The results are presented in Table 1.1

Table 1.1. Correlations between school environment and adjustment to secondary school

\begin{tabular}{|l|l|c|c|}
\hline \multicolumn{2}{|c|}{} & $\begin{array}{c}\text { School } \\
\text { Environme nt }\end{array}$ & $\begin{array}{c}\text { Adjustment to } \\
\text { Secondary School }\end{array}$ \\
\hline \multirow{2}{*}{$\begin{array}{l}\text { SCHOOL ENVIRONMEN T } \\
\text { Eyy }\end{array}$} & Pearson Correlation & 1 & \\
\cline { 2 - 4 } & Sig. (2-tailed) & & \\
\cline { 2 - 4 } & $\mathrm{N}$ & $.585^{* *}$ & 1 \\
\hline ADJUSTMENT & Pearson Correlation & .000 & 290 \\
\cline { 2 - 4 } & Sig. (2-tailed) & 290 & \\
\hline & $\mathrm{N}$ & \\
\hline
\end{tabular}


Correlation on school environment influence on adjustment result was $r(290)=.59, p=000$. This indicates that there was a significant relationship between school environment and adjustment of form one students to secondary school. The analysis also revealed that there was a positive association between school environment and adjustment of form one students to secondary school. Therefore, it was concluded that the school environment was a major determinant in settling down of students in secondary school. The conclusion drawn is that school environment determined how form one students adjusted to secondary school.

\begin{tabular}{|c|c|c|c|c|c|c|c|c|}
\hline \multicolumn{6}{|c|}{$\begin{array}{l}\text { Table 1.2. School Environment influence on } \\
\text { Adjustment of form students to secondary school }\end{array}$} & & & \\
\hline & & $\begin{array}{l}\text { Mod } \\
\text { el Sum } \\
\text { mar y }\end{array}$ & & & & \multicolumn{3}{|c|}{ ANOVA Summary } \\
\hline Mo de 1 & $\mathrm{R}$ & $\begin{array}{c}\mathrm{R} \\
\text { Squ are }\end{array}$ & $\begin{array}{c}\text { Adj } \\
\text { uste d R } \\
\text { Squ are }\end{array}$ & $\begin{array}{l}\text { Std. Error } \\
\text { of the } \\
\text { Estimate }\end{array}$ & $\begin{array}{l}\text { Durbin- } \\
\text { Watson }\end{array}$ & df & $\mathrm{F}$ & $\mathrm{P}$ \\
\hline 1 & $.585^{\mathrm{a}}$ & $\begin{array}{c}34 \\
2\end{array}$ & $\begin{array}{l}.34 \\
0\end{array}$ & .42695 & 1.746 & 1 & $\begin{array}{l}149 . \\
906\end{array}$ & .000 \\
\hline \multicolumn{9}{|c|}{ a. Predictors: (Constant), SCHOOL ENVIRONMENT } \\
\hline \multicolumn{6}{|c|}{$\begin{array}{l}\text { b. Dependent Variable: ADJUSTMENT TO } \\
\text { SECONDARY SCHOOL }\end{array}$} & & & \\
\hline
\end{tabular}

From Table 1.2 results of regression mode on school environment, $\mathrm{R}=0.585$ indicate that school environment had a positive influence on adjustment of form one students to secondary school. The model further indicates that school environment explained $34.2 \%$ of adjustment of form one students to secondary school as depicted by the $\mathrm{R}^{2}$. These results are significant as explained by the F-ratio of 149.906 hence independent variable had a significant effect on the dependent variable.

Table 1.3. Coefficient of Regression Model between School Environment and Adjustment of form one students to secondary school

\begin{tabular}{|c|c|c|c|c|c|c|}
\hline \multirow{2}{*}{\multicolumn{2}{|c|}{$\begin{array}{c}\text { Model } \\
\text {. }\end{array}$}} & \multicolumn{2}{|c|}{$\begin{array}{c}\text { Unstandardized } \\
\text { Coefficients }\end{array}$} & \multirow{2}{*}{$\begin{array}{c}\text { Standardized } \\
\text { Coefficients } \\
\text { Beta }\end{array}$} & \multirow[t]{2}{*}{$\mathrm{t}$} & \multirow[t]{2}{*}{ Sig. } \\
\hline & & $\mathrm{B}$ & Std. Error & & & \\
\hline & (Constant) & 1.339 & .179 & & 7.493 & .000 \\
\hline & $\begin{array}{l}\text { SCHOOL } \\
\text { ENVIRONMENT }\end{array}$ & .593 & .048 & .585 & 12.244 & .000 \\
\hline
\end{tabular}

a. Dependent Variable: ADJUSTMENT TO SECONDARY SCHOOL

The coefficient of regression model between school environment and adjustment of form one students to secondary school had $(\beta=0.585, p=0.05)$. This implies that a unit change in school environment will change adjustment to secondary school by 0.585 units. Hence, the regression model about influence school environment on adjustment of form one students can be stated as:

$Y=\alpha+\beta_{1} X_{1}+\varepsilon ;$ Hence $Y=1.339+0.048+0.42695$

Where $\bullet \mathrm{Y}$ is the dependent variable: adjustment of form one students to secondary school.

- $\alpha=$ a constant or the intercept

- $\mathrm{X}_{1}$ is the independent variables: School environment and $\varepsilon$ the error term reflecting other factors that influence adjustment of form one students to secondary school.

In summary, regression results indicate that school environment significantly influence adjustment of form one students to secondary school. The conclusion then drawn is that the kind of school environment that the form one students find them in goes a long way in determining their adjustment to secondary school. Therefore, form one students would be happy in a supportive and friendly. That well organized and labeled structures allow easy location of the same by form one students hence smooth school adjustment. The opposite that is a harsh and hostile secondary school environment with unlabeled structures may make secondary school unpleasant for form one students hence difficult to adjust and instead opt for unpleasant behavior. These may include persistent absenteeism, faked illness and even school dropout. 


\section{DISCUSSION}

The school environment included social environment which involved: relations with administrators, teachers, and other students, class atmosphere and physical environment such as: buildings and its arrangements, play grounds, library and other physical facilities and learning resources. This study"s findings indicate that all these aspects collectively influence adjustment of form one to secondary school. The Correlation result were $(\mathrm{r}=0.585, \rho<0.05)$, showed a very significant influence of school environment on adjustment of form one students to secondary school. The regression results $(\beta=0.585, p=0.05)$, indicate that school environment significantly influence adjustment of form one students to secondary school. The conclusion drawn from these results is that school environment has a significant influence on adjustment of form one students to secondary school. Therefore, there is need for secondary schools to cultivate a school environment that is warm, conducive and accommodative in order to meet students" needs hence higher academic achievement and better socioemotional health. The study established that form one student would be happy in a school environment that is warm, conducive and accommodative with well labeled, adequate and accessible learning facilities and resources. They pointed out that play grounds should be spacious and that there should freedom for form one students in particular to participate in games sports and other co-curricular activities without any restriction or discrimination.

A conducive school environment according to this study"s findings is one with an organized classroom sitting arrangement. Further, the physical structures and buildings should be easy to locate through proper layout out, arrangements and proper labeling. In fact, a conducive school environment shield student against portrayal of problematic behaviors like absenteeism, faked illness, disinterest on school activities, joining negative peers and even opting for early school dropout. These negative consequences may arise due to lack of a conducive secondary school environment. This study"s findings are consistent with findings that a healthy school climate is essential to positive student development hence directly linked to other key indicators for success. These include: academic achievement, high completion rates, effective risk prevention, and student retention (Faster, \& Lopez, 2013; Thapa, Cohen, Higgins \& Guffey, 2012; Allensworth \& Easton, 2007). Further, when students feel safe, supported by significant others, they get fully engaged in school activities hence in a better position to learn and are more fully equipped with the skills they need to succeed in school and beyond. Bru, Stornes, Munthe and Thuen (2010) confirm that when students feel supported by significant others in the school environment, they become motivated and enjoy learning hence get focused to school work. This implies that they experience positive social and emotional wellbeing which in turn contribute school adaption and retention.

\section{CONCLUSIONS AND RECOMMENDATIONS}

Supportive and warm school environment make form one student become motivated to remain in school be focused to school work, enjoy teaching and learning activities hence retention and graduation from high school, and entry into college. Problematic behaviours like absenteeism, faked illness, disinterest on school activities, joining of negative peers and even opting for early school dropout are less prevalent in a supportive and warm school environment. Therefore, students need to be taught social skills like those of making friends for use during school adjustment and later in life not in making or forming the most solid and stable friendships. Further, there is need for all stake holders to team up and create or cultivate a school environment that is supportive and warm hence, meets students" social and academic needs resulting to higher academic achievement which will see such students to higher levels of learning like universities and colleges. A supportive and warm school environment also leads to better socio-emotional health especially for form one students within and beyond school.

[1]. Shah K. J. A Study on Social Maturity, School Adjustment and Academic Achievement among Residential School Girls. Journal of Education and Practice, 3,7, 173-222. 2012.

[2]. Achoka, J. S. K., Odebero, S.O., Maiyo, J.K., \& Mualuko, N. J. (2007). "Access to basic education in Kenya: inherent concerns.” Educational Research and Review, 2 (10), 275-284.

[3]. Cohen, L., Marion, L., \& Morrison, K.(2005). Research Methods in Education (5 ${ }^{\text {th }}$ ed.). New York: Routledgefalmer.

[4]. Saunders, M., Lewis, P. \& Thornhill, A. (2003). Research methods for business students ( $3^{\text {rd }}$ ed). London: Pearson Professional Ltd. Edinburgh gates.

[5]. Akos, P. (2004). Advice and student agency in the transition to middle school. Research in Middle Level Education, 27,1-11.

[6]. Allensworth, $\quad$ E. M., \& Easton, J. Q. (2007). What matters for staying on-track and graduating in Chicago Public High Schools: A close look at course grades,failures, and attendance in freshman year. Chicago, IL: University of Chicago, Consortium on Chicago School Research. 
[7]. Benner, D. A., \& Graham, S. (2009). The Transition to High School as a Developmental Process Among Multiethnic Urban Youth. Child Development, 80(2),356-376.

[8]. Bronfenbrenner, U. (1979). The ecology of human development. Cambridge, MA: Harvard University Press.

[9]. Bru, E., Stornes, T., Munthe , E., \& Thuen, E. (2010). Students' perceptions of teacher support across the transition from primary to secondary school. Scandinavian Journal of Educational Research, 54, 6, 519-533.

[10]. Crandell, L. T., Corrine, H. C. J., \& Vander-Zanden,W. (2009).Human Development( $9^{\text {th }}$ Ed.). McGraw Hill Companies, Inc. New York.

[11]. Darmody, M. (2008). Mapping Barriers to Successful School Transitions in Comparative Perspective Irish and Estonian Experiences. TRAMES: A Journal of the Humanities and Social Sciences. 12 (62/57), $1,51-72$.

[12]. Ding, C.S. (2008). Variations in academic performance trajectories during high school transition: Exploring change profiles via multidimensional scaling growth profile analysis. Educational Research and Evaluation. 14, 4, 305-319.

[13]. Dockett, S. \& Perry,B.(2007). Starting School - A Handbook for Early Childhood Educators, NSW: Pademelon Press.

[14]. Dube,A. K.(2011). Factors Affecting Transition, Performance and Retention of Girls" in Secondary Schools in Arid and Semi Arid Land. A Case of Rhamu Town - Mandera County,Kenya. Unpublished M.Phip Thesis, Africa Nazarene University, Nairobi, Kenya.

[15]. Faster, D. \& Lopez, D. (2013). School climate and assessment. School Climate Practices for Implementation and Sustainability. A School Climate Practice Brief, Number 1, New York, NY: National School Climate Center.

[16]. Frey, A., Ruchkin, V., Martin, A. and Schwab-Stone, M. (2009) Adolescents in Transitions: School and Family Characteristics in the Development of Violent Behaviors Entering High School. Child Psychiatry and Human Development, 40, 1-13.

[17]. Howard, S. \& Johnson, B. (2004). Transition from primary to secondary school: Possibilities and paradoxes. Paper presented at the Annual Conference of the Australian Association for Research in Education Conference, Melbourne. http://www.aare.edu.au/04pap/how04184.pdf

[18]. Interface: Listening to the Students" Voice. Research in Science Education, 38, 501-527.

[19]. Kiuru, N., Nurmi J., Aunola K., Salmela - Aro, K. (2009). Peer group homogeneity in adolescents" school adjustment varies according to peer group type and gender. International Journal of Behavioral Development 33 (1) 65-76

[20]. Lerner, R.M. \& Steinberg, L.E. (2009).Handbook of Adolescent Psychology ( $3^{\text {rd }}$ ed ). New Jersey: Hoboken.

[21]. Lipps, G. (2005). Making the Transition: The Impact of Moving from Elementary to Secondary School on Adolescents" Academic Achievement and Psychological Adjustment. Ottawa, Ontario: Statistics Canada.

[22]. Logan, M. \& Skamp, K. (2008). Engaging Students in Science Across the Primary Secondary Martin, A. J., \& Dowson, M. (2009). Interpersonal relationships, motivation, engagement, and achievement: Yields for theory, current issues, and educational practice. Review of Educational Research, 79, 327-365.

[23]. Republic of Kenya. Laws of Kenya. 2008a. The Education Act, Chapter 21. Nairobi, Kenya:

[24]. Thapa, A., Cohen, J., Higgins - DeeAlessandro, A., \& Guffey, S. (2012). School Climate Research Summary: School Climate Brief, No.3. National School Climate Center, NewYork, NY. Retrieved from: http://www.schoolclimate.org/climate/research.php.

[25]. Vasalampi, K. Salmela-Aro K., Nurmi, J. (2009). Adolescents self concordance, school engagement, and burnout predict their educational trajectories. European psychologist, 14 (4).

[26]. Weller, S. (2007). „Sticking with your mates?": Children“"s Friendship Trajectories during the Transition from Primary to Secondary School. Children \& Society, 21, 339-351.

[27]. inga, M. A., Agak, J.O., \& Ayere A. M. (2011).The Relationship among The Relationship among School Adjustment, Gender and Academic Achievement amongst Secondary School Students in Kisumu District Kenya. Journal of Emerging Trends in Educational Research and Policy Studies, 2 (6): 493-497.

[28]. Wang, T. M., \& Holcombe, R. (2010). Adolescents" perceptions of school environment, engagement, and academic achievement in middle school. American Education Research Journal , 47(3), 633-662. http://dx.doi.org/10.3102/0002831209361209. 
Appendices

Table 1.4 Descriptive on Students Information Concerning School Environment Influence

\begin{tabular}{|c|c|c|c|c|c|c|c|c|c|}
\hline \multirow{2}{*}{$\begin{array}{l}\text { Statements of students information } \\
\text { concerning school environment }\end{array}$} & \multirow{2}{*}{\begin{tabular}{|l|} 
N \\
Statistic
\end{tabular}} & \multirow{2}{*}{\begin{tabular}{|l} 
Minimum \\
Statistic
\end{tabular}} & \multirow{2}{*}{\begin{tabular}{|l|} 
Maximum \\
Statistic
\end{tabular}} & \multirow{2}{*}{\begin{tabular}{|l|} 
Mean \\
Statistic
\end{tabular}} & \multirow{2}{*}{\begin{tabular}{|l|} 
Std. \\
Deviation \\
Statistic
\end{tabular}} & \multicolumn{2}{|c|}{ Skewness } & \multicolumn{2}{|c|}{ Kurtosis } \\
\hline & & & & & & Statistic & Std. & Statistic & Std. Error \\
\hline $\begin{array}{l}\text { like my new school it has a } \\
\text { small students and staff } \\
\text { populations. } \\
\text { I learnt my school environment }\end{array}$ & 290 & 1 & 5 & 2.19 & 1.590 & .887 & .143 & -.903 & .285 \\
\hline $\begin{array}{l}\text { easily on arrival day( buildings } \\
\text { are few and well labeled) } \\
\text { I like my new school because } \\
\text { administrator, teachers and non }\end{array}$ & 290 & 1 & 5 & 2.76 & 1.696 & .256 & .143 & -1.639 & .285 \\
\hline $\begin{array}{l}\text { teaching staff are caring, } \\
\text { understanding and } \\
\text { accommodative }\end{array}$ & 290 & 1 & 5 & 4.17 & 1.181 & -1.340 & .143 & .837 & .285 \\
\hline $\begin{array}{l}\text { Teachers and administrators } \\
\text { encourage us to participate in } \\
\text { extra curricula activities( sports, } \\
\text { games clubs etc) }\end{array}$ & 290 & 1 & 5 & 4.30 & 1.311 & -1.774 & 143 & 1.670 & .285 \\
\hline $\begin{array}{l}\text { We are treated well by others } \\
\text { senior students in the school } \\
\text { I like mv new school routines and }\end{array}$ & 290 & 1 & 5 & 3.47 & 1.395 & -.463 & 143 & -.992 & .285 \\
\hline $\begin{array}{l}\text { duties because they are student- } \\
\text { friendly }\end{array}$ & 290 & 1 & 5 & 3.70 & 1.470 & -.753 & 143 & -.871 & .285 \\
\hline $\begin{array}{l}\text { Form ones are not harassed or } \\
\text { bullied in this school }\end{array}$ & 290 & 1 & 5 & 4.30 & 1.261 & -1.715 & .143 & 1.616 & .285 \\
\hline $\begin{array}{l}\text { The clas sroom environment is } \\
\text { warm becau se teachers don't } \\
\text { threaten but encourage us }\end{array}$ & 290 & 1 & 5 & 4.11 & 1.263 & -1.325 & .143 & .628 & .285 \\
\hline $\begin{array}{l}\text { Clas smates are cooperative and } \\
\text { focused }\end{array}$ & 290 & 1 & 5 & 4.20 & 1.116 & -1.268 & .143 & .772 & .285 \\
\hline $\begin{array}{l}\text { Ilearn best through lecture } \\
\text { method than other methods e.g } \\
\text { discovery and discussion. } \\
\text { Subject teacher are approachable }\end{array}$ & 290 & 1 & 5 & 2.95 & 1.648 & .040 & .143 & -1.599 & .285 \\
\hline $\begin{array}{l}\text { and willing to help in their } \\
\text { subject areas. }\end{array}$ & 290 & 1 & 5 & 4.43 & 1.047 & -1.927 & .143 & 2.980 & .285 \\
\hline $\begin{array}{l}\text { I do not fear asking questions in } \\
\text { class } \\
\text { Class }\end{array}$ & 290 & 1 & 5 & 4.01 & 1.367 & -1.122 & .143 & -.132 & .285 \\
\hline $\begin{array}{l}\text { Class teachers are caring, } \\
\text { approachable and listen to } \\
\text { pers onal and clas s problem }\end{array}$ & 290 & 1 & 5 & 4.44 & 1.071 & -2.008 & .143 & 3.196 & .285 \\
\hline $\begin{array}{l}\text { We choose our desk mate on our } \\
\text { own }\end{array}$ & 290 & 1 & 5 & 3.14 & 1.780 & -.156 & .143 & -1.774 & .285 \\
\hline $\begin{array}{l}\text { We were asked to choo se class } \\
\text { prefect on our own }\end{array}$ & 290 & 1 & 5 & 4.30 & 1.343 & -1.776 & .143 & 1.559 & .285 \\
\hline $\begin{array}{l}\text { Teacher moves round the clas s, } \\
\text { helping individual students }\end{array}$ & 290 & 1 & 5 & 3.40 & 1.578 & -.418 & .143 & -1.370 & .285 \\
\hline $\begin{array}{l}\text { Teacher reinforce and reward } \\
\text { students attempts/answers }\end{array}$ & 290 & 1 & 5 & 3.73 & 1.445 & -.817 & .143 & -.705 & .285 \\
\hline Valid N (listwise) & 290 & & & & & & & & \\
\hline
\end{tabular}

